\title{
14. State control and self-censorship in the media after the coup
}

\section{Russell Hunter}

\section{Government/media relations post independence}

Fiji's media grew exponentially in the three decades following independence. With that growth and diversification came a radically altered relationship between the media and the government.

At independence the media consisted of The Fiji Times, then a reliably pro-establishment organ, and the government radio station, which, while nominally independent, could be relied upon not to rock the boat too much. By 2006, Fiji had three national dailies, a range of magazines, a flourishing independent radio industry and a monopoly television broadcaster. Per head of population Fiji had and continues to have among the greatest choice of local media in the world. This is highly unlikely to continue to be the case, of which more later.

It is likely that this increased diversity - and increased competition - pushed the media into a more independent, even adventurous, frame of mind, as each outlet fought fiercely to establish and/or maintain market share. In the media there is no more deadly executioner than a bored audience.

The friction between the media and the government perhaps reached its height in December 1996, when the Rabuka government first said it would approve my appointment as editor-in-chief of The Fiji Times. On the basis of this approval, I left my job on The Australian in Sydney and travelled to Suva - only to discover that the Fiji government had changed its mind. It took the joint intervention of Prime Minister Rabuka and Home Affairs Minister Paul Manueli to have my work permit approved. It was to become a depressingly familiar experience.

The Fiji Times had been perceived as anti-Rabuka-government (as opposed to anti-government) - which may well have been a fair assessment from the point of view of the cabinet. But The Fiji Times had quite rightly taken a very firm line on the National Bank of Fiji scandal, roasting the government mercilessly on what was arguably the worst and most expensive debacle in Fiji's short history. Apart from the $\$ 220$ million it cost the people of Fiji there was another, less immediately obvious, outcome. This was the propensity of this and successor governments to, often quite deliberately, confuse the national interest with the government's interest. The affair also established a lasting atmosphere of tension between government and media. This tension, however, was, if anything, 
healthier for the national good than was the all-too-cosy relationship that had prevailed.

Perversely, when the media and the government were in something resembling an accord in the run-up to the 1999 election - with what was at the time described or perhaps hailed as the Rabuka-Reddy concordat - the people of Fiji overwhelmingly rejected the government, bringing the Fiji Labour Party (FLP)-led People's Coalition to power with, by Fiji standards, a convincing election victory. The country's first and so far only prime minister of Indian descent, Mahendra Chaudhry, rode a wave of multicultural goodwill and national optimism the like of which Rabuka and Reddy could not have imagined. Chaudhry, however, lost the general goodwill within a matter of months - and blamed the media. His justification - or the lack of it - in so apportioning culpability is less relevant here than the fact that Chaudhry became convinced of his own rhetoric - that the media had a 'hidden agenda' to unseat him. The media in general responded that the agenda was so well hidden that none of them could find it. The Fiji Times ventured so far as to say that Chaudhry had his own hidden agenda, which was to pick a fight with the media in order to concoct a reason to introduce harsh and government-imposed controls. In a particularly angry speech to the Pacific Islands News Association convention in Suva that year Chaudhry warned of legislation if the media did not mend its ways. Mahendra Chaudhry's dislike (or worse) of the media was now in the public arena - and Chaudhry has never been one not to act on his dislikes or to refrain from settling scores, real or imagined.

In early 2000, The Fiji Times' request to extend my work permit was declined and, after a judicial review upheld the Chaudhry government's right to make that decision, I left Fiji on 3 May 2000 - Press Freedom Day - only to return on 12 August to the news (to me) that I was suspected by sections of the, by now media-paranoid, FLP of being in some way connected with the Speight coup that had toppled the Chaudhry government. Otherwise, it was suggested, why would I have come back? Of course, there was no connection whatsoever but the myth, as myths do, lived on.

The fact that the post-coup Qarase government fared no better with the media than had its predecessor made little impact on the closed minds of the myth-makers, and the voice of the FLP was unusually stilled as the nation's fourth coup, in December 2006, drew ominously nearer. Despite their widespread opposition to the Qarase government's overtly racist and divisive policies, the section of the media that routinely expresses editorial opinion, the daily newspapers, was unanimous in the view that another coup would be nothing short of catastrophic for Fiji. Thus was the stage set for a confrontation, the result of which is likely to be a much truncated and state-controlled media in Fiji. 


\section{The immediate post-coup impact on the media}

When the Republic of Fiji Military Forces took over the running of the country on 5 December 2006, its leaders could not have been unaware that it did so against a background of almost unanimous media disapproval, if not outright hostility. And when Mahendra Chaudhry emerged as the most powerful of the interim line ministers, the media knew there would be challenging times ahead. For, if the military distrusted the media, Chaudhry detested it - or at least those sections of it over which he could not exercise control.

Within days of the takeover, coup-maker and self-appointed interim Prime Minister Commodore Voreqe Bainimarama declared that he would uphold media freedom, a statement of which The Fiji Times, somewhat forlornly, reminded him daily, directly above its masthead on its front page. Nevertheless, within days of the coup, the military moved. A team of soldiers appeared in uniform at The Fiji Times' office in central Suva, announcing that they were there to ensure that no 'inciteful' material would find its way into the newspaper's pages. A team of soldiers was to be posted in the newsroom to vet all content. Courageously and rightly, The Fiji Times declined to publish under such circumstances. The paper's senior management declared that it would cease publication until the soldiers were removed. A military team also visited the offices of the Fiji Sun on the same evening but arrived only as the last truck was leaving the premises with the next day's issue, giving the Fiji Sun an advantage over its rival, which did not publish.

The following morning, Commodore Bainimarama declared that it had all been a mistake, a miscommunication, and the soldiers were withdrawn. However, it is all but certain that, had The Fiji Times management not stood firm, military censorship would have been imposed.

The Fiji Times editorial stance was resolutely opposed to the coup, its instigators and its ramifications. It was illegal, trumpeted the Times, as was the appointed interim government and all its doings. The Fiji Daily Post, controlled as it was by Laisenia Qarase's nephew, was, in the military mind, beyond the pale. The Fiji Sun adopted the slightly more pragmatic view that the military-backed interim government was a fact that had to be dealt with, while opposing the quite dreadful military excesses that were beginning to emerge.

It is a matter of record that quite harmless dissenters were rounded up late on Christmas Eve 2006, taken to the military camp in Suva and tortured. Others who voiced disapproval were hunted down and given similar treatment. A former minister, overheard criticizing the military in a Suva bar was, within minutes, taken by a team of soldiers to the military HQ and beaten after having been forced to run around the parade square. One man died, beaten to death, while in military custody for reasons that remain unclear. Another died as a 
result of being in military and police custody. The trials of the suspects, arrested and charged months later, proceed at snail's pace.

What is not recorded is the military's intimidation of the media, which was as brutal as it was pervasive. One employee, who to this day prefers to remain anonymous for fear of a return visit by military thugs, was savagely beaten by a gang of up to ten men unworthy of the name soldiers. His medical report was a litany of serious injuries inflicted by blunt instruments, mostly army boots. The mental injuries inflicted on him and his family can only be guessed at. This man had been wrongly identified as a journalist. In fact, he worked in the company's administration section and had no connection with, or influence on, editorial policy. No apology has been received and no charges have been laid. An official complaint to the Fiji Human Rights Commission was, in effect, fobbed off. When the man's chief executive officer complained to the military he was told to keep quiet about the incident or risk a repeat.

A photographer who recorded the somewhat violent arrest of a suspect was kicked, punched and bodily thrown into the back of an army ute. He was detained at the camp for several hours. When his employer organization complained, it received the warning: 'If you say he was beaten, he will be'. The media organization, fearing for the safety of its staff member, reported that he had been 'manhandled'.

Late one Friday evening in January 2007, the military arrived in what appears to have been platoon strength at the home of the Fiji Sun's political editor. Armed with assault rifles, they demanded that he come out. Luckily for him, but less so for his seriously traumatized family, he was away at the time. The soldiers told his wife that her husband was required to appear before a senior military officer at $2 \mathrm{pm}$ the following day. He did so, waited until $4 \mathrm{pm}$ and went back to work. The following day he was summoned again, this time by telephone, and, after another long wait, was ushered in only to be told he had to 'tone it down a bit'. Asked what precisely was meant by that, the officer would only repeat the phrase. To the present day, this very senior journalist has not been told what was expected of him.

There were other threats, including one from a senior officer who would, he said, 'come and get me' if the Fiji Sun did not retract a particularly frivolous piece from New Zealand that the editor had elected to publish. But by now a pattern was emerging: Any media organization that published or broadcast something the regime did not particularly savour could expect a threat of violence. The accuracy or otherwise of the material did not appear to be an issue as far as the government and the military were concerned. Its very existence was sufficient to generate angry threats.

The print media, in particular the daily newspapers, came in for special attention. In a conversation with the independent chair of the Fiji Media Council, 
Commodore Bainimarama expressed his extreme anger and dissatisfaction with the dailies. He did not give a specific reason and, since such conversations ceased after this encounter, it has not been possible to ascertain one. Nevertheless, it was abundantly clear that the interim prime minister's anger was profound. Whether or not this reflected the view of his minister of finance is not known.

\section{Self-censorship}

It was at about this time that self-censorship began to become apparent in the nation's media. There was neither arrangement nor agreement on this; it was simply born of fear for the safety of personnel and the survival of individual businesses. By this time publisher of the Fiji Sun, I recall making the point very strongly to the senior editorial staff that we would better serve our readers by continuing to publish than by going down with all guns firing. Judging by the coverage and comment, this appeared to be the prevailing view across the industry. Thus, the military's routine denials of what was frequently undeniable were published and broadcast. A page one report and picture on the abduction and torture of the so-called democracy activists, with the central figure in a neck brace, explained merely that she had forgiven her 'alleged' attackers. But at least the newspaper published the story, even if not in the way that might have been expected. The other media ignored it. This was just one example of self-censorship at work. There were many others, of greater or lesser import, but what emerged from the months of self-censorship was a media prepared to accept restrictions in return for survival. Despite winning what might be called the first round - with The Fiji Times' refusal to accept military censorship - the media backed down by 'recognizing the need' for self-censorship, resulting in readers, listeners and viewers being deliberately and knowingly less than well served.

A major difficulty at that time was the absence of guidance from the military as to what would and what would not be considered acceptable. Possibly deliberately vague statements on 'inciteful' comments left editors wondering what the reaction might be to any given story. It also gave the military the excuse to intervene on a case-by-case basis without having to lay out a cohesive policy. Thus, decisions about whether or not to publish were now driven not only by truth and public interest but also, increasingly, by concern over what the military might think and how it might react. It was a fateful retreat, and Fiji's media may well wish to examine its behaviour - though, as will be seen, any such exercise may well be academic. The experience taught the military and the interim administration that media control was not only desirable, but also achievable.

The media cooperated by 'controlling' its coverage during the time of the emergency regulations imposed by the interim administration after the coup, but these could not be imposed indefinitely if the support of aid partners and 
regional neighbours were to be maintained or recovered. With the lifting of the emergency regulations came a ray of hope for the media. The print media again led the way with news reports and commentaries that might not have run - at least not in that form - under the emergency regulations. There was surprise, relief and not a little confusion when it became clear that there would be no hostile military reaction and that journalists were not threatened. The media began to do what it and most of its audience regarded as its job. Editors felt able to publish news and comment based on what they saw as the public interest rather than on the anticipated reaction of the authorities. Fiji again had a media whose diversity offered a growing range of content. It was a false dawn.

\section{The Fiji Human Rights Commission and the Anthony Report}

The Fiji Human Rights Commission (FHRC) was established under the 1997 constitution to oversee and protect the human rights of all those living within the Fiji jurisdiction. It can hear and adjudicate on complaints. It can make recommendations to the government. It can take up and prosecute the complaints of the downtrodden, the mistreated and the marginalized. It is in many ways a court of last resort for those who feel their human rights have been infringed.

The FHRC, then, was the obvious forum for redress for those tortured, humiliated and intimidated by the regime and its military puppeteers after the coup. Those seeking such redress, however, were almost universally doomed to disappointment. Those, for example, deemed by the FHRC to have accepted private apologies from the military were informed that there was nothing further the Commission could do. Meanwhile, the Commission's director, in a public report, had reached what ousted Vice-President and former High Court judge Ratu Joni Madraiwiwi described as the 'perplexing' conclusion that there had been no coup in December 2006 as the ousted Qarase government had been illegal in the first place. The media was less restrained, describing the report as bizarre, incredible and unfathomable. Many leading lawyers were equally flummoxed, one taking the public view that law was far too serious a subject for sociologists such as the director (who also has a law degree) to pronounce upon. The director, through the chair of the Fiji Media Council, sent a message to the publishers of the Fiji Sun and The Fiji Times that she would not hesitate to take action if further derogatory comments were offered - to which both replied that they would take that advice under consideration. No legal action was ever forthcoming but that was not to be the end of the matter.

In the meantime, the FHRC director - soon to become commissioner - was increasingly and overtly offering support for what most of her fellow lawyers regarded as an illegal regime. The structure of the FHRC is that the commissioners set policy, which is implemented by the director. However, by this time the director was acting alone, claiming the imprimatur of the FHRC for actions that the commissioners clearly neither condoned nor ordered. This culminated in an 
exercise that would represent the greatest threat to the independence of the nation's media in modern times.

In August 2007 advertisements appeared in the dailies calling for submissions to an FHRC-commissioned inquiry into the independence of the nation's media. Most media representatives were deeply suspicious of the terms of reference; they asked for clarification, which to the present day has not been forthcoming. In the absence of a reply, most began to form the view that the inquiry was no more than another attempt to deliver control of the nation's media to the State, and declined to take part in the exercise without clarification of the terms of reference - which, in the event, were for the most part ignored by the consultant brought in from Hawai'i to deliver judgment, Dr James Anthony. Dr Anthony, 74, was not the director's first choice by a long way. A number of lawyers and academics declined the consultancy; a New Zealand-based race relations specialist agreed to take on the task only to withdraw at the last moment. This, said the director, was the result of illegal interference by New Zealand-based Pacific reporter and prohibited immigrant Michael Field who would be 'dealt with'. He's still waiting to be 'dealt with'.

The irascible Dr Anthony arrived in Suva and spent some three weeks doing 'research'. This took the form of anonymous interviews, which he seemed to accept at face value where it suited his preconceived and openly admitted view that Fiji's media was a 'white man's club' run by a cabal of eight or so white expatriates who met in secret conclave to decide what would and what would not be published or broadcast. An invitation from the Fiji Sun - in response to his report - for him to spend as much time in their offices as he wished in order discover how ridiculously warped that view was, and to learn how fiercely competitive the media had become since he had left the country more than half a century ago, was ignored.

Dr Anthony's report is a shockingly sloppy piece of work, especially considering his claim to academic credentials. It is a litany of factual inaccuracy, hate speech, non sequiturs and blatant misrepresentation, all interlaced with a thick rope of racism that, had it been written by and of another race, would have been deemed 'inciteful'. All of his so-called informants hid behind anonymity. Their statements are no more than opinion offered as fact, the like of which would cause a first year journalism student to be failed. He railed against the figments of his own racial bitterness in, for example, calling for the removal of all foreign - that is to say white - journalists working in Fiji. His research seemed to have missed the fact that there were none. His conclusions were founded on totally unreliable and inaccurate observations and anonymous opinions unworthy of the term research. At best, his racial bitterness was cynically used by sections of the government, through the FHRC director, to produce the report they wanted; at 
worst, he permitted his personal prejudices to overcome the basic tenets of proper academic research.

One of his recommendations was that a seven per cent levy be imposed on all media advertising and all licence income in order to finance a media tribunal. This body would oversee the media and, among other punishments, impose fines on erring journalists, their editors and organizations. The process to be followed was not specified, but it is impossible to even imagine that membership of such a tribunal would escape State appointment and thus control. The money raised by the levy would also be used to establish a media training authority to 'train' journalists and promote a close and harmonious relationship between the State and the media - much along the lines of the Singapore model. Just how that model could be successfully imposed on Fiji - any more than could the Queensland Road Traffic Act - was not explained.

The end result would, indeed, be to deliver control of the media into the hands of the State - but there would be little left to control. Unless the accountants and lawyers can find legal ways around the legislation - or more likely the decree - the seven per cent Anthony levy will cripple this vibrant and growing industry. The likely survivors are The Fiji Times and Fiji Television, though the ability of both to provide quality local content will be drastically reduced. The government radio stations - assuming they will be subject to the levy - will need ever more public funds to stay alive. The future for the rest will be bleak indeed. When asked by me in a radio debate what he had to say to those who would lose their livelihoods as a result of his report, Dr Anthony had no answer. He was equally unable to give a straight answer when asked if he was aware that there were no foreign - white or otherwise - journalists working in Fiji and that the only three foreign white personnel were in managerial as opposed to editorial positions.

Curiously, Dr Anthony's research seemed focused on relations between the People's Coalition government of 1999-2000 and the media, or more precisely the battle between Mahendra Chaudhry and the media. Both Qarase governments had had, if anything, a testier time with the media and they had also sought to gain control through a media bill, which was eventually abandoned due to widespread public opposition. Equally curiously, the staunch opposition to that bill by the then director, and now commissioner, of the FHRC was not recorded in Anthony's report.

Meanwhile, not long before Dr Anthony arrived in Fiji, a page one report appeared in the Fiji Sun saying that a member of the interim government had failed to submit tax returns for three years. The following day, August 7, an official complaint on the matter was made to the police commissioner by a former staff member of the Fiji Islands Revenue and Customs Authority (FIRCA); no action was taken by the authority. The story, however, created a tidal wave of 
public interest, which only intensified some 10 days later when a subsequent Fiji Sun report revealed that the same minister had failed to pay tax on, or even disclose the existence of, bank accounts held in Australia and New Zealand. Thus began a long-running series of news reports and feature articles by Sun columnist Victor Lal, a former Fiji journalist and now an Oxford-based academic. They created a storm of interest.

\section{Expulsions}

As the Lal reports gained momentum, the question on the nation's lips was increasingly: Who is the minister? In fact, however, the identity was one of Fiji's worst-kept secrets, the name easily available on any number of internet blogs and freely passed by word of mouth. Finally, in The Fiji Times of 22 February, Chaudhry challenged the media to name the minister at the centre of the furore. He didn't have long to wait - the following day the Times page one splash read: 'It's Chaudhry'. The next day, 24 February, the Fiji Sun followed with another Lal exclusive: 'Now for the REAL story - how Chaudhry got his millions', a detailed account of Mr Chaudhry's no-longer-secret bank accounts, with detailed documentation of deposits and withdrawals. The fact that one of the deposits AU\$500,000 - was channeled through the Indian Consulate in Sydney attracted particular attention. The government of India has yet to explain it.

The following day, 25 February, while driving home from work at about 8pm, I received a call on my cell phone from an acquaintance who informed me that Mr Chaudhry's son, Rajendra, had been telling people that I would be out of the country by the following Wednesday. My partner and I were discussing this when two men arrived at our house claiming to be from the department of immigration. One of them probably was. Dressed in a departmental uniform, he was affable, said 'bula', shook my hand and advised that he was sorry to arrive so late but had been to our previous address and had only just managed to locate me. He asked for my passport, explaining there was a minor anomaly to be cleared up. Foolishly, perhaps, I gave it to him. He then asked to see my partner's passport as well as that of our 13-year-old daughter. He returned theirs but not mine, all the while insisting that we talk not in the house but under the light in the driveway. As he slipped my passport into a manila folder he withdrew from the folder a green government form signed by the permanent secretary for immigration; it gave me seven days in which to leave the country. The departmental representative asked me to go with him to his office to 'arrange the formalities', but when he could not or would not say what these formalities might be I declined to go, pointing out that the order gave me seven days to leave and that I intended to comply with it. On his repeated insistence that I accompany him, I began to call the company lawyer.

Almost immediately, four or five people - obviously military but unarmed and out of uniform - burst into the compound calling 'let's go now', 'hurry up', 'get 
in the vehicle' and so forth. One even brought my shoes from the porch. 'Don't waste our time', shouted the driver of the waiting twin-cab 'just get in the vehicle'. They told my wife and the company lawyer that they were taking me to their office in Suva. So, crammed into the rear of the twin-cab between two burly soldiers, I was whisked off into the night. It soon became plain that the destination was not Suva but Nadi, the site of the international airport. My mobile phone was taken from me a minute or so into the journey and, on arriving in Nadi, I was held in isolation at a house in Cawa Street until the next morning, when a different group of four soldiers took me to the airport. The Fiji Sun has been able to identify the Suva-based army captain who escorted me to Air Pacific flight FJ911 bound for Sydney. I was wearing the clothes I had been wearing when abducted the night before. I had next to no money with me.

Meanwhile, the Fiji Sun lawyer, some good friends and the Australian High Commission had been active. High Commissioner James Batley's repeated demands for consular access to me was met with a wall of silence from officials, all of whom denied knowledge of my whereabouts. Our lawyer, sensing what was going on, had arranged for an early morning court sitting, at which he was granted an injunction preventing the state from removing me from the country. It was ignored.

About an hour from Sydney, my passport was returned to me by one of the extremely sympathetic and seemingly ashamed cabin crew, along with the green form I had seen the night before. The words 'seven days' were by now blacked out. I was met at Sydney airport by a horde of TV, radio and print journalists - which confirmed my view that the Fiji military had once again shot itself in the foot as far as public and international relations were concerned.

The familiar denials followed. This was an exercise carried out solely by the immigration department with no military involvement whatsoever, it was alleged: The chief executive officer of the Fiji Sun had been deported because he was a threat to national security based on 'credible' evidence. This evidence has never been produced, although there was a hint that an illegally hacked email exchange between myself and Lal proved the case. The mail in question had been obtained by a disgruntled former employee who appears to have sold it to a third party. It also reached Nikhil Singh in Sydney, an ex-Fiji TV reporter and now FLP mouthpiece employed by the journalists' trade union, which, as part of its mission statement, is sworn to uphold media freedom. Singh emailed the material to the Fiji and the regional media, most representatives of which regarded it as a typical exchange between a reporter and publisher and ignored it as irrelevant. The notable exceptions were Fiji TV and the government radio station.

I have still not been told why I was abducted from my home and deported, though it was frequently stated that it was in no way connected with the Fiji Sun's coverage of the Chaudhry tax saga. At this time I was receiving a host of 
calls and emails. Referring to the denials, one caller paraphrased William Shakespeare: 'Methinks they dost protest too much'.

Again curiously, some ten days after my removal, Mr Chaudhry gave an interview to the government radio station, purporting to 'clear the air on Russell Hunter'. The interview included the following statements by Mr Chaudhry:

The deportation of Russell Hunter has nothing to do with my own case. But it has been made out as if he was deported from here because he was writing about me when there is no truth about it. ...Mr Hunter was still in Fiji for eight and a half years as a publisher. He was supposed to train a local a long time ago but he kept renewing his work permit. ...[H]e has [had] a grudge against me [since] I was the minister for information. I refused to renew his work permit and specifically his work permit was that he must train a local to take over which he did not do....[W]e did not review his work permit, he took us to court and lost in the court case but then the 2000 coup happened and the Qarase government allowed him to stay. How can a foreign journalist stay here for eight and a half years without training a local and getting renewal of work permit?

This is revealing. When the People's Coalition government had declined to renew my work permit in 2000, then Prime Minister Chaudhry had told all who inquired (including the managing director of my then employer, The Fiji Times) that he was not dealing with my case and had no knowledge of it. He referred all inquiries to his Attorney-General. It has taken him eight years to reveal the truth - that it was entirely his decision. Readers can decide who has a grudge. They can also decide whether the coverage of Chaudhry's tax affairs had 'nothing to do' with my treatment.

So, depending on who anyone chooses to believe, I was abducted from my home in the dead of night by a gang of thugs for not training a replacement, or I was abducted from my home in the dead of night by a gang of thugs for being some unspecified security risk. I have still not been told why I received such treatment and I no longer expect to be told.

And Chaudhry would certainly be aware that while at The Fiji Times and again at the Fiji Sun I had designed and implemented training programs for cadets, reporters, sub-editors and editors. He would also be aware that when I was appointed publisher and CEO of the Fiji Sun (a non-editorial position) my former understudy at The Fiji Times replaced me as editor-in-chief and continues to hold that position. He would be equally aware that the government is the nation's biggest employer of expatriate personnel and that at least one consultant in his very own FIRCA has been in place for more than 30 years without being required or even invited to train a local replacement. 
In a poignant postscript to my abrupt departure from Fiji, some friends, acquaintances, supporters and the merely curious gathered for a farewell function. It was a very emotional occasion, during which a friend of the senior civil servant who had cooperated in my deportation order told my wife that the senior civil servant in question prayed daily for forgiveness and that he also sought forgiveness from us. I choose not to record my wife's answer. However, if he reads this, as I imagine he will, he will know that I have forgiven him. Life's too short to hold grudges, Mr Chaudhry.

A week after the Times publication of the tax story, Chaudhry issued a defamation writ claiming $\$ 1$ billion in damages. The Fiji Sun expected a similar claim. Both have announced their intention to defend these actions.

However, some three months on no writ had been received by the Sun, and the Times case had not progressed. And with the forced departure of Times publisher, Evan Hannah, on May 1, 2008, it seems a reasonable bet that there is no intention on the part of Chaudhry to pursue the case.

Mr Hannah was taken from his home, by the same group that abducted me, on the eve of World Press Freedom day - and a day after the interim Prime Minister had declared that his government supported media freedom. It is clear that it supports media freedom only within the ambit of government control and that it intends to implement the Anthony report, discredited as it is.

And, finally, the senior civil servant whom I have forgiven played exactly the same role in the deportation of Hannah. Mr Hannah is not a vindictive person and will in all likelihood offer forgiveness if asked. But from how many others will this man seek forgiveness? 